\title{
Impact of Liver Biopsy on the Decision to Treat Patients with Chronic Hepatitis B Genotype D Virus Infection
}

\author{
Ahmed Ali Al-Qahtani ${ }^{a}$ Hamad Ibrahim Al-Ashgar ${ }^{b}$ Mohammed Noreen Al-Ahdal ${ }^{a}$ \\ Hadeel Al Mana ${ }^{c}$ Ali Soliman Ali ${ }^{d}$ Ahmed Farouk Hasanain ${ }^{d}$ Ahmed Helmy ${ }^{b, d}$ \\ ${ }^{a}$ Department of Infection and Immunity, The Research Center, ${ }^{b}$ Section of Gastroenterology, Department of Medicine, \\ and ${ }^{\mathrm{C} D e p a r t m e n t}$ of Pathology, King Faisal Specialist Hospital and Research Centre, Riyadh, Saudi Arabia; ${ }^{\mathrm{d} D e p a r t m e n t}$ \\ of Tropical Medicine and Gastroenterology, Assiut University Hospital, Assiut, Egypt
}

\section{Key Words}

Genotype D · Histopathology · Fibrosis · Viral load ·

Transaminases - Therapy

\begin{abstract}
Objectives: Patients with chronic hepatitis B virus (HBV) may exhibit significant liver pathology despite alanine aminotransferase (ALT) and HBV DNA levels below the cutoff values advised by treatment guidelines. We evaluated candidacy for HBV therapy when baseline histopathological changes are taken into consideration. Methods: Clinical, biochemical, serological, virological, and histopathological (METAVIR score) data of 117 patients with HBeAg-negative chronic HBV genotype D were collected and analyzed. Results: Significant pathology ( $\geq F 2$ and/or $\geq A 2)$ and fibrosis $(\geq F 2 \pm \geq A 2)$ were found in $73(62.4 \%)$ and $59(50.4 \%)$ patients, respectively. Based on HBV DNA $(>2,000 \mathrm{IU} / \mathrm{ml})$ and ALT levels $>2 \times 40 \mathrm{U} / \mathrm{I}$ (the standard cutoff value), only 31 (26.5\%) patients were candidates for therapy. This increased to $58(49.6 \%)$ patients when the new ALT cutoff values (30 U/I for males, and $19 \mathrm{U} / \mathrm{I}$ for females) were applied. Relying on either $\geq F 2$ and/or $A \geq 2$ or $\geq F 2 \pm \geq A 2$ increases the treatment candidacy to 73 (62.4\%) and 59 (50.4\%) patients, respectively. Also, when compared with standard ALT cutoff
\end{abstract}

values, applying both new ALT cutoff values with either significant pathology or fibrosis increases treatment candidacy to $28(23.9 \%)$ and 42 (35.9\%) patients, respectively. Conclusion: Liver pathology is more reliable than ALT and HBV DNA in the decision to treat patients with $\mathrm{HBeAg}$-negative chronic HBV genotype D.

(c) 2014 S. Karger AG, Basel

\section{Background}

Hepatitis B virus (HBV) infection is a major cause of morbidity and mortality with an estimated 350-400 million chronically infected persons worldwide [1]. Chronic $\mathrm{HBV}$ infection in Mediterranean and Middle East countries including Egypt and Saudi Arabia, is characterized epidemiologically by (1) an intermediate endemicity (overall HBsAg prevalence of 6.7\%) [1,2], (2) prevalence of a $\mathrm{HBeAg}$-negative variant in $>80 \%$ of patients $[2,3]$ which represents the late phase of infection where HBV pre-/basic core promoter variants are predominant with reduced or abolished HBeAg expression [4, 5], and (3) predominant HBV genotype $\mathrm{D}$ [3] which is more often associated with $\mathrm{HBeAg}$-negative variants [6] and more severe liver disease [7], which is characterized by persis-

\section{KARGER}

E-Mail karger@karger.com

www.karger.com/int
(C) 2014 S. Karger AG, Basel

0300-5526/14/0575-0248\$39.50/0
Dr. Ahmed Helmy

Department of Tropical Medicine and Gastroenterology, 6th Floor

Assiut University Hospital

Assiut 71517 (Egypt)

E-Mail ahsalem10@yahoo.com 
Fig. 1. Flow chart of the patients included in the study. $\mathrm{DM}=$ Diabetes mellitus; $\mathrm{HDV}=$ hepatitis D virus; $\mathrm{HCC}=$ hepatocellular carcinoma.

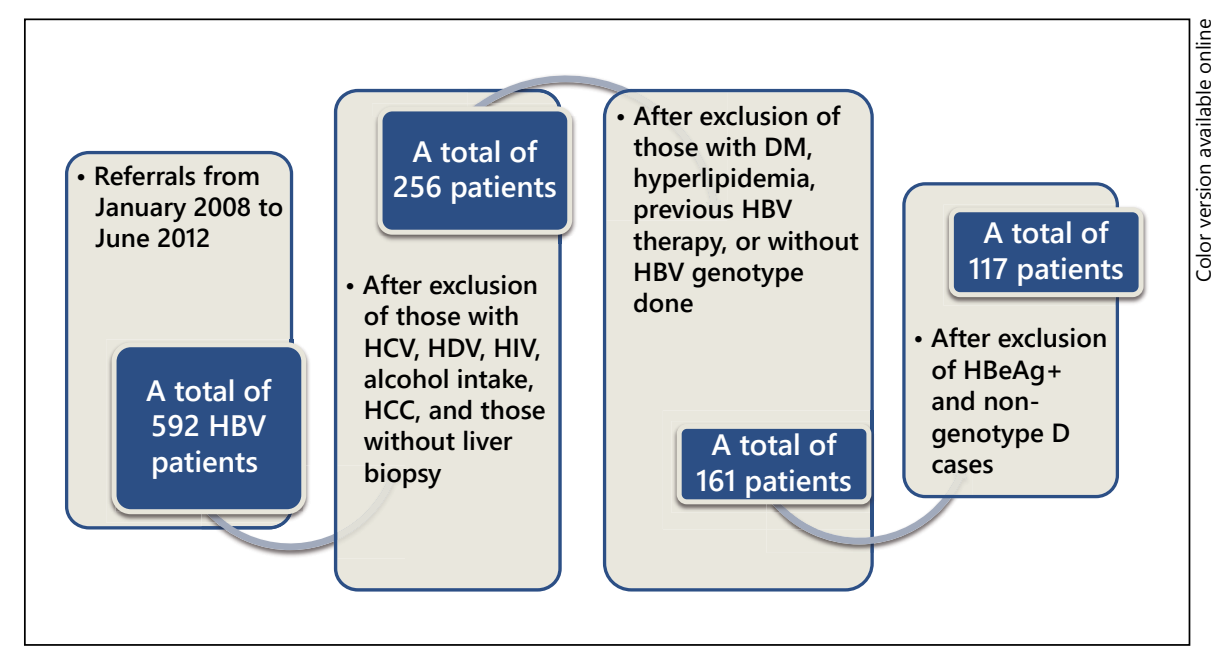

tent viral replication, progression of liver disease, and early development of cirrhosis $[8,9]$.

The available HBV treatment guidelines are similar [10-13], despite geographical differences in the epidemiology of the disease [14]. According to the American Association for Study of Liver Diseases (AASLD) 2007 guidelines, the parameter used to determine candidacy for treatment of HBeAg-negative patients is HBV DNA $\geq 2,000 \mathrm{IU} / \mathrm{ml}$ and alanine aminotransferase $($ ALT) $\geq 2 \times$ the upper limit of normal (ULN). However, patients with lower ALT and/or HBV DNA levels may have abnormal histology and are consequently at increased risk of chronic liver disease complications [13]. Therefore, the new guidelines recommended a new lower ULN ALT and aspartate aminotransferase (AST) of $30 \mathrm{U} / \mathrm{l}$ for men and 19 $\mathrm{U} / \mathrm{l}$ for women $[11,13]$.

ALT and HBV DNA levels do fluctuate, necessitating frequent monitoring or performing liver biopsy to assess disease activity, grade of fibrosis, and eligibility for treatment [13]. Additionally, the REVEAL study has indicated that patients with HBV DNA $<2,000 \mathrm{IU} / \mathrm{ml}$ are also at risk of disease progression [15]. Moreover, assessing liver histopathology was advised by the AASLD for evaluation of histologic disease in chronic HBV patients presenting with normal ALT and low HBV DNA levels [11].

Therefore, the main objective of this study in patients with chronic HBV infection was to evaluate whether incorporation of liver histopathological changes affects the decision to treat chronic HBV, HBeAg-negative, genotype D, which is prevalent in the Middle East and Mediterranean area, and influences the candidacy to treat such patients compared to the current strategies that rely mainly on serum ALT and HBV DNA levels.

\section{Patients and Methods}

\section{Patients}

A flow chart of patients included in the study is shown in figure 1. Briefly, 592 chronic hepatitis B patients attending our Viral Hepatitis Clinic from January 2008 to May 2012 were found to have chronic HBV infection.

\section{Exclusion Criteria}

After excluding cases with concomitant HCV, HIV, hepatitis delta infections, and those with hepatocellular carcinoma, alcoholic liver disease, diabetes mellitus, and hyperlipidemia, we were left with 256 patients with isolated HBV infection. Only 161 patients remained after further exclusion of cases without liver biopsy (not done because of failure to obtain consent, clinical contraindication), those with nontypable HBV DNA, patients with previous anti-HBV therapy, and those with decompensated liver disease. After excluding patients positive for $\mathrm{HBeAg}$ and those with non-D genotypes, a total of 117 patients were included in this analysis.

\section{Inclusion Criteria}

The 117 patients enrolled in this study fulfilled the following inclusion criteria after obtaining institutional approval and written informed consent: HBsAg-positive test for $>6$ months, HBeAgnegative or negative detectable HBV DNA by polymerase chain reaction, recently performed liver biopsy, determined HBV genotype, no prior treatment with interferon or neucleos(t)ide analogues, and absence of the above exclusion criteria.

\section{Laboratory Tests}

Routine liver biochemical tests were performed using commercially available autoanalyzers, and hepatitis serological markers were assayed using commercially available enzyme-linked immunoassays (Clinotech Diagnostics). According to the instructions of the manufacturer, the ULN for ALT was determined to be $40 \mathrm{U} / 1$ (Bicon Diagnostik, Germany). Quantitative HBV DNA levels were measured by a COBAS TaqMan System (Roche Diagnostics Corporation, Indianapolis, Ind., USA), which has a lower detection limit of $30 \mathrm{IU} / \mathrm{ml}$. Genotyping was performed using an INNOLiPA HBV genotyping assay (Innogenetics N.V., Ghent, Belgium). 
Table 1. Subject characteristics $(\mathrm{n}=117)$

\begin{tabular}{lc}
\hline Variable & Result \\
\hline Age, years & \\
$\quad$ Mean \pm SD & $36.6 \pm 11.6$ \\
$\quad$ Median (range) & $37(14-70)$ \\
Age group, n (\%) & \\
$\quad \leq 40$ years & $80(68.4)$ \\
$\quad>40$ years & $37(31.6)$ \\
Sex, $\mathrm{n}(\%)$ & $97(82.9)$ \\
$\quad$ Male & $20(17.1)$ \\
Female & $85.3 \pm 130.2$ \\
ALT, U/l & $53.5(9-925)$ \\
$\quad$ Mean \pm SD & \\
Median (range) & $47.2 \pm 50.5$ \\
AST, U/l & $31(13-357)$ \\
$\quad$ Mean \pm SD & \\
Median (range) & $1.1 \times 10^{7} \pm 2.7 \times 10^{7}$ \\
HBV DNA, IU/ml & $2.13 \times 10^{4}\left(37\right.$ to $\left.1 \times 10^{8}\right)$ \\
$\quad$ Mean \pm SD & $60(51.3)$ \\
Median (range) & $57(48.7)$ \\
Inflammatory grade, $\mathrm{n}(\%)$ & $58(49.6)$ \\
$0-1$ & $59(50.4)$ \\
2-4 &
\end{tabular}

Table 2. Significant liver pathology by viral load and ALT level

\begin{tabular}{|c|c|c|c|}
\hline Variable/levels & $\mathrm{n}(\%)$ & $\geq \mathrm{F} 2$ & $\begin{array}{l}\geq \mathrm{F} 2 \text { and/or } \\
\geq \mathrm{A} 2\end{array}$ \\
\hline \multicolumn{4}{|l|}{ HBV DNA } \\
\hline $\begin{array}{l}<2,000 \mathrm{IU} / \mathrm{ml} \\
2,000 \text { to }<20,000\end{array}$ & $23(19.7)$ & $8(13.6)$ & $12(16.4)$ \\
\hline $\mathrm{IU} / \mathrm{ml}$ & $32(27.4)$ & $12(20.3)$ & $14(19.2)$ \\
\hline$\geq 20,000 \mathrm{IU} / \mathrm{ml}$ & $62(53.0)$ & $39(66.1)^{3}$ & $47(64.4)^{5}$ \\
\hline \multicolumn{4}{|l|}{$\mathrm{ALT}^{1}$} \\
\hline$\leq 1 \times \mathrm{ULN}$ & $54(46.2)$ & $15(25.4)^{4}$ & $22(30.1)^{4}$ \\
\hline$>1 \times$ to $<2 \times \mathrm{ULN}$ & $29(24.8)$ & $22(37.3)$ & $24(32.9)$ \\
\hline$\geq 2 \times U L N$ & $34(29.1)$ & $22(37.3)$ & $27(37.0)$ \\
\hline \multicolumn{4}{|l|}{$\mathrm{ALT}^{2}$} \\
\hline$\leq 1 \times \mathrm{ULN}$ & $18(15.4)$ & $3(5.1)$ & $7(9.6)$ \\
\hline$>1 \times$ to $<2 \times \mathrm{ULN}$ & $34(29.1)$ & $10(16.9)$ & $13(17.8)$ \\
\hline$\geq 2 \times U L N$ & $65(55.6)$ & $46(78.0)^{4}$ & $53(72.6)^{4}$ \\
\hline Total & 117 & 59 & 73 \\
\hline
\end{tabular}

Data expressed as $\mathrm{n}(\%) .{ }^{1}$ Using the standard cutoff value of $40 \mathrm{U} / \mathrm{l} .{ }^{2}$ Using the new cutoff values of $30 / 19 \mathrm{U} / \mathrm{l} .{ }^{3} \mathrm{p}=0.016$. ${ }^{4} \mathrm{p}=0.000 .{ }^{5} \mathrm{p}=0.005$.
Assessment of Liver Histopathology

All patients $(\mathrm{n}=117)$ included in this study had ultrasoundguided liver biopsies (hematoxylin and eosin stains for morphological evaluation and Masson's trichrome stain for fibrosis assessment). Liver specimens were adequate in size (at least $15 \mathrm{~mm}$ long) and $>6$ portal tracts were assessed. All liver biopsy specimens were assessed and scored according to the METAVIR scoring system [16] by a single experienced hepato-histopathologist (H.A.) who was blinded to all clinical and virological results. Patients with inflammatory grade $\geq \mathrm{A} 2$ and/or those with fibrosis stage $\geq \mathrm{F} 2$ were considered to have significant pathology.

\section{Statistical Analysis}

Data were collected initially in a specialized data collection form and transferred to the Statistical Package for Social Sciences version 15.0 (SPSS, Chicago, Ill., USA) for analysis. Means of continuous variables were compared using Student's t tests, nonparametric tests (Wilcoxon and Mann-Whitney), or one-way analysis of variance (ANOVA) with a post-hoc test (Tukey's) as appropriate. A $\chi^{2}$ or Fisher's exact test was used to compare ratios and proportions. $\mathrm{p}<0.05$ was considered statistically significant. Correlation between continuous variables with skewed distribution was tested by Spearman's rank correlation.

\section{Results}

\section{Baseline Patient Characteristics}

We analyzed 117 patients with chronic HBV, HBeAgnegative, genotype $\mathrm{D}$ after exclusion of those who were HBeAg positive $(\mathrm{n}=31)$ and those who were non-genotype $\mathrm{D}(\mathrm{n}=16)$. Of these, $97(82.9 \%)$ male patients and 20 female patients, aged $14-70$ years ( median $=37$ ), were included in the study. HBV DNA levels ranged from 32 to $1 \times 10^{8} \mathrm{IU} / \mathrm{ml}\left(\right.$ median $\left.=2.13 \times 10^{4}\right)$ and the ALT level ranged from 9 to $925 \mathrm{U} / \mathrm{l}($ median $=53.5)$, while AST ranged from 13 to $357 \mathrm{U} / \mathrm{l}$ (median $=31$ ). Moderate-tosevere inflammation ( $\geq \mathrm{A} 2)$ was detected in 57 (48.7\%) patients, and significant fibrosis $(\geq \mathrm{F} 2)$ and significant pathology ( $\geq \mathrm{F} 2$ and/or $\geq \mathrm{A} 2)$ were found in $59(50.4 \%)$ and $73(62.4 \%)$ patients, respectively (table 1$)$.

Relation between HBV DNA and Liver Histopathology

According to the AASLD guidelines, 2007 standards, taking an HBV DNA level of 2,000 IU/ml as a cutoff value for HBeAg-negative patients, our results showed that 8 of 23 patients (34.8\%) with a serum HBV DNA level $<2,000$ $\mathrm{IU} / \mathrm{ml}$ had stage 2 or higher fibrosis $(\geq \mathrm{F} 2)$, and 12 of them (52.2\%) had fibrosis $\geq \mathrm{F} 2$ and/or inflammation grade 2 or more $(\geq A 2)$. Patients with HBV DNA $>20,000 \mathrm{IU} / \mathrm{ml}$ showed significantly more hepatic pathology $(\geq \mathrm{F} 2)$ and ( $\geq \mathrm{F} 2$ and/or $\geq \mathrm{A} 2$ ) compared to patients with lower HBV DNA ( $\mathrm{p}=0.016$ and 0.005 , respectively; table 2 ). 
Table 3. Comparison between the number and percentage of patients who need to be treated according to the strategies used: pathology, ALT, and HBV DNA levels

\begin{tabular}{|c|c|c|c|c|}
\hline Question & $\begin{array}{l}\text { Standard ALT cutoff value } \\
\text { and HBV DNA (strategy } 1 \text { ) }\end{array}$ & $\begin{array}{l}\text { New cutoff ALT values } \\
\text { and HBV DNA (strategy 2) }\end{array}$ & $\begin{array}{l}\geq \mathrm{F} 2 \pm \geq \mathrm{A} 2 \\
(\text { strategy } 3)\end{array}$ & $\begin{array}{l}\geq \mathrm{F} 2 \text { and } / \text { or } \geq \mathrm{A} 2 \\
\text { (strategy } 4 \text { ) }\end{array}$ \\
\hline \multicolumn{5}{|l|}{ Decision to treat } \\
\hline Not a candidate & $86 / 117(73.5)$ & $59 / 117(50.4)$ & $58(49.6)$ & $44(37.6)$ \\
\hline \multicolumn{5}{|l|}{ Cases missed } \\
\hline Compared to strategy 4 & $42 / 117(35.9)$ & $15 / 117(12.8)$ & $14 / 117(12.0)$ & - \\
\hline
\end{tabular}

Data expressed as $\mathrm{n} / \mathrm{n}(\%) .{ }^{1} \mathrm{ULN}=40 \mathrm{U} / \mathrm{l} .{ }^{2} \mathrm{ULN}=19 \mathrm{U} / \mathrm{l}$ for females and $30 \mathrm{U} / \mathrm{l}$ for males.

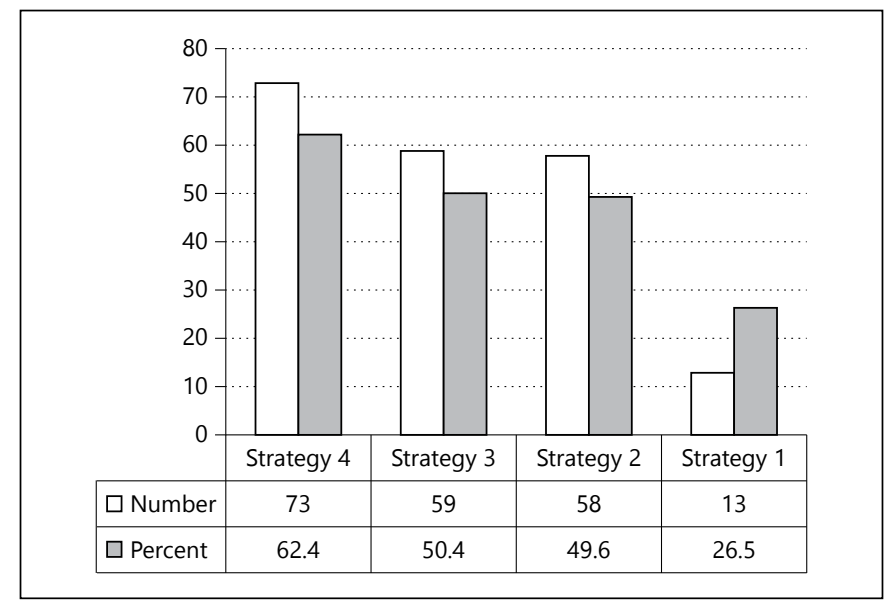

Fig. 2. Number and percentage of patients that need to be treated. Decision 1: based on raised HBV DNA and standard ALT cutoff value $(40 \mathrm{U} / \mathrm{l})$ irrespective of pathology results. Decision 2: based on raised HBV DNA and new ALT cutoff value (19/30 U/1) irrespective of pathology results. Decision 3: based on presence significant fibrosis ( $\geq \mathrm{F} 2 \pm \geq \mathrm{A} 2$ ). Decision 4 : based on presence of and significant pathology ( $\geq \mathrm{F} 2$ and/or $\geq \mathrm{A} 2)$.

Relation between ALT Level and Liver Histopathology

According to the AASLD guidelines, 2007 standards, using an ALT cutoff value of $40 \mathrm{U} / \mathrm{l}$, our results showed that 15 of 54 patients $(27.8 \%)$ with serum ALT levels $\leq 1 \times$ ULN (40 U/l) had fibrosis stage $\geq F 2$, and 22 of them (40.7\%) had $\geq \mathrm{F} 2$ and/or $\geq \mathrm{A} 2$. However, patients with ALT $\leq 1 \times$ ULN showed significantly less hepatic pathology: $\geq \mathrm{F} 2$ and $\geq \mathrm{F} 2$ and/or $\geq \mathrm{A} 2$ compared to those with higher ALT levels ( $p=0.000$ for both; table 2). Even with the new reduced ALT cutoff values, 3 of 18 patients (16.7\%) with serum ALT levels $\leq 1 \times \mathrm{ULN}(19 / 30 \mathrm{U} / \mathrm{l}) \mathrm{had}$ stage $\geq \mathrm{F} 2$, and 7 of them (38.9\%) had fibrosis $\geq \mathrm{F} 2$ and/or $\geq$ A2 (table 2). Patients with ALT levels $\geq 2 \times$ new ULN (19/30 U/l) had significantly more hepatic pathology: $\geq F 2$ and $\geq \mathrm{F} 2$ and/or $\geq \mathrm{A} 2$ compared to those with lower ALT levels ( $\mathrm{p}=0.000$ for both; table 2 ).

\section{Candidacy to Treatment Decision}

Based on serum HBV DNA $(>2,000 \mathrm{IU} / \mathrm{ml})$ and ALT levels $>2 \times 40 \mathrm{U} / \mathrm{l}$ (the standard cutoff value), only $31(26.5 \%)$ patients were candidates for therapy. This increased to $58(49.6 \%)$ patients when the new ALT cutoff values (30 U/l for males, and $19 \mathrm{U} / \mathrm{l}$ for females) were applied. For the start of therapy, implementation of significant fibrosis ( $\geq \mathrm{F} 2 \pm \geq \mathrm{A} 2$ ) or significant liver pathology $(\geq \mathrm{F} 2$ and/or $\geq \mathrm{A} 2)$ increased patient eligibility for therapy to $59(50.4 \%)$ and $73(62.4 \%)$, respectively (table 3; fig. 2). This increased the candidacy for therapy by $1(0.9 \%)$ and $15(12.8 \%)$ patients, respectively. Furthermore, the application of the new lower ALT cutoff values and either $\geq \mathrm{F} 2 \pm \geq \mathrm{A} 2$ and $\geq \mathrm{F} 2$ and/ or $\geq \mathrm{A} 2$ further increased the candidacy for treatment by $28(23.9 \%)$ and $42(35.9 \%)$ patients, respectively, which would have been missed if we had only relied on strategy 1 (table 3).

\section{Discussion}

We believe that the current international guidelines that rely mainly on HBV DNA and ALT levels for the decision on how to treat patients with chronic HBV infection require regular reevaluation. Based on our results and those of others [17], liver histopathology, but not $\mathrm{HBV}$ genotype, needs to be incorporated more in future 
practice guidelines. Currently available guidelines recommend observation of HBV-infected patients, especially those with viral load above the threshold and normal ALT level $[10,12,13]$, whereas the Keeffe algorithm considers liver biopsy and treatment when biopsy reveals fibrosis [11], particularly in patients above the age of 40 years.

Recent reports revealed that $12-45.5 \%$ of patients with chronic HBV infection and persistently normal ALT levels have fibrosis stage $\geq F 2$ [18-21], and that age $>40$ years is an independent predictor of significant pathology. This together with our results suggest that the future management guidelines of this patient group should recommend assessing hepatic pathology either by biopsy or by its alternative noninvasive modalities such as a FibroScan and/or FibroTest of hepatic fibrosis.

Our patients had HBeAg-negative disease, which usually needs closer follow-up and frequent monitoring [22]. This requires not only extra costs, but also patient awareness and education, as most of these patients are asymptomatic. In addition, many of these patients present at an older age with significant hepatic pathology and persistent viral replication [7-9]. In addition, our patients have HBV genotype D, the predominant type in Saudi Arabia and other Middle East countries like Egypt [3,23]. Unfortunately, this genotype is known to be associated with the HBeAg-negative variant [6], and with more severe liver disease [7]. Therefore, patients with HBV infection, especially those with genotype $\mathrm{D}$ and the $\mathrm{HBeAg}$-negative variant, may need earlier liver biopsy rather than frequent laboratory follow-up with ALT and HBV DNA evaluations, which are often fluctuating, particularly HBV DNA levels [24]. This view is supported by the Keeffe algorithm, which considers therapy in patients with known significant histological disease even if ALT is within the normal range and HBV DNA is low [11].

In this study, $50 \%$ of $\mathrm{HBeAg}$-negative patients exhibited significant liver pathology and were associated with normal or slightly elevated ALT level (table 2). This supports the concept that lower HBV DNA levels (3-5 $\log _{10}$ $\mathrm{IU} / \mathrm{ml}$ ) may be associated with progressive liver disease and therefore warrants treatment [13].
The more recent guidelines recommend reducing the ULN ALT and AST to $30 \mathrm{U} / 1$ for men and $19 \mathrm{U} / \mathrm{l}$ for women $[11,13]$. Applying these new values in the present study increased the eligible patients for treatment by $23.1 \%$ (27 patients; table 3 ). We have also shown more patients with significant fibrosis $(\geq \mathrm{F} 2 \pm$ $\geq \mathrm{A} 2)$ and significant pathology ( $\geq \mathrm{F} 2$ and/or $\geq \mathrm{A} 2)$ in patients with higher HBV DNA levels (61.1 and 64.4\% respectively; table 3 ). This is consistent with previous reports in $\mathrm{HBeAg}$-negative patients $[17,25,26]$. These results are not universal as HBV DNA load and ALT levels failed to predict disease activity in other studies [27-29].

Detection of significant liver pathology ( $\geq \mathrm{F} 2$ and/or $\geq \mathrm{A} 2)$, or significant fibrosis $(\geq \mathrm{F} 2 \pm \geq \mathrm{A} 2)$ increased the number of cases eligible for treatment to 59 (50.4\%) and $73(62.4 \%)$, respectively. This increased the candidacy to therapy by $42(35.9 \%)$ and $28(23.9 \%)$ patients, respectively. Despite the increased use of transient elastography (FibroScan) in the assessment of hepatic fibrosis, liver biopsy is still the gold standard due to the discordance of the available literature $[30,31]$.

Liver biopsy remains an important tool in the diagnosis and management of parenchymal liver diseases. However, it remains an invasive procedure with certain unavoidable risks and complications as well as shortcomings in diagnostic accuracy, as a large liver sample is required for an ideal assessment. It is also open to observer interpretation and prone to sampling errors [32]. In recent years, a number of noninvasive biomarkers with an impressive range of diagnostic certainty approaching that achieved with liver biopsies have evolved [33]. These noninvasive tests represent a lower-cost option, are easily reproducible, and serve as suitable alternatives to assess hepatic fibrosis.

In conclusion, liver biopsy is more reliable than both ALT and HBV DNA levels in the decision to treat patients with $\mathrm{HBeAg}$-negative chronic HBV genotype $\mathrm{D}$, even with implementation of the recommended lower ALT levels. Whether to replace liver biopsy with the currently evolving noninvasive measure is a debatable issue that warrants future investigations.

\section{References}

1 McMahon BJ: Epidemiology and natural history of hepatitis B. Semin Liver Dis 2005; 25(suppl 1):3-8.

2 al-Faleh FZ, Ayoola EA, Arif M, et al: Seroepidemiology of hepatitis $B$ virus infection in
Saudi Arabian children: a baseline survey for mass vaccination against hepatitis B. J Infect 1992;24:197-206.

3 Abdo AA, Al-Jarallah BM, Sanai FM, et al:Hepatitis B genotypes: relation to clinical outcome in patientswith chronichepatitis Bin Saudi Arabia. World J Gastroenterol 2006;12:7019-7024.

$\checkmark 4$ Chu CJ, Keeffe EB, Han SH, et al: Prevalence of HBV precore/core promoter variants in the United States. Hepatology 2003;38:619-628.
Al-Qahtani/Al-Ashgar/Al-Ahdal/ Al Mana/Soliman Ali/Hasanain/Helmy 
5 Funk ML, Rosenberg DM, Lok AS: Worldwide epidemiology of $\mathrm{HBeAg}$ negative chronic hepatitis B and associated precore and core promoter variants. J Viral Hepat 2002;9:52-61.

6 Thakur V, Guptan RC, Kazim SN, et al: Profile, spectrum and significance of HBV genotypes in chronic liver disease patients in the Indian subcontinent. J Gastroenterol Hepatol 2002;17:165-170

7 Sanchez-Tapias JM, Costa J, Mas A, et al: Influence of hepatitis $B$ virus genotype on the long-term outcome of chronic hepatitis B in western patients. Gastroenterology 2002;123: 1848-1856.

8 Bonino F, Rosina F, Rizzetto M, et al: Chronic hepatitis in HBsAg carriers with serum HBV-DNA and anti-HBe. Gastroenterology 1986;90:1268-1273.

-9 Brunetto MR, Oliveri F, Coco B, et al: Outcome of anti-HBe positive chronic hepatitis $B$ in alpha-interferon treated and untreated patients: a long-term cohort study. J Hepatol 2002;36:263-270

10 de Franchis R, Hadengue A, Lau G, et al: EASL International Consensus Conference on Hepatitis B. 13-14 September, 2002 Geneva, Switzerland. J Hepatol 2003;39(suppl 1):S3S25.

$\checkmark 11$ Keeffe EB, Dieterich DT, Han SH, et al: A treatment algorithm for the management of chronic hepatitis B virus infection in the United States: an update. Clin Gastroenterol Hepatol 2006;4:936-962.

12 Liaw YF, Leung N, Guan R, et al: Asian-Pacific consensus statement on the management of chronic hepatitis B: a 2005 update. Liver Int 2005;25:472-489.

13 Lok AS, McMahon BJ: Chronic hepatitis B. Hepatology 2007;45:507-539.

14 Lau G, Marcellin P, Peters M: Chronic hepatitis $\mathrm{B}$ : a global health problem requiring coherent worldwide treatment strategies. Hepatol Int 2007;1:316-325.
15 Iloeje UH, Yang HI, Su J, et al: Predicting cirrhosis risk based on the level of circulating hepatitis B viral load. Gastroenterology 2006; 130:678-686.

16 Intraobserver and interobserver variations in liver biopsy interpretation in patients with chronic hepatitis C. The French METAVIR Cooperative Study Group. Hepatology 1994; $20: 15-20$

17 El-Zayadi A, Badran HM, Saied A, Shawky S, Attia ME, Zalata K: Evaluation of liver biopsy in Egyptian HBeAg-negative chronic hepatitis $B$ patients at initial presentation: implications for therapy. Am J Gastroenterol 2009; 104:906-911.

18 Lai M, Hyatt BJ, Nasser I, et al: The clinical significance of persistently normal ALT in chronic hepatitis B infection. J Hepatol 2007; 47:760-767.

19 Tsang PS, Trinh H, Garcia RT, et al: Significant prevalence of histologic disease in patients with chronic hepatitis B and mildly elevated serum alanine aminotransferase levels. Clin Gastroenterol Hepatol 2008;6:569-574.

20 Wang CC, Lim LY, Deubner H, et al: Factors predictive of significant hepatic fibrosis in adults with chronic hepatitis $\mathrm{B}$ and normal serum ALT. J Clin Gastroenterol 2008;42:820826.

21 Sanai FM, Helmy A, Bzeizi KI, et al: Discriminant value of serum HBV DNA levels as predictors of liver fibrosis in chronic hepatitis $\mathrm{B}$. J Viral Hepat 2011;18:e217-e225.

22 Hadziyannis SJ, Vassilopoulos D: Hepatitis B e antigen-negative chronic hepatitis $\mathrm{B}$. Hepatology 2001;34:617-624.

23 El-Zayadi A, Saber M, Lavanchy D, et al: High frequency of $\mathrm{HBeAg}$ minus chronic $\mathrm{HBsAg}$ positive liver disease in Egypt. Int Hepatol Commun 1995;3:178-183.

24 Chu CJ, Hussain M, Lok AS: Quantitative serum HBV DNA levels during different stages of chronic hepatitis B infection. Hepatology 2002;36:1408-1415.
25 Lindh M, Horal P, Dhillon AP, et al: Hepatitis $B$ virus DNA levels, precore mutations, genotypes and histological activity in chronic hepatitis B. J Viral Hepat 2000;7:258-267.

26 Zavaglia C, Mondazzi L, Maggi G, et al: Are alanine aminotransferase, hepatitis $\mathrm{B}$ virus DNA or IgM antibody to hepatitis B core antigen serum levels predictors of histological grading in chronic hepatitis B? Liver 1997;17: 83-87.

27 Ter Borg F, Ten Kate FJ, Cuypers HT, et al: Relation between laboratory test results and histological hepatitis activity in individuals positive for hepatitis B surface antigen and antibodies to hepatitis B e antigen. Lancet 1998;351:1914-1918.

28 Crockett SD, Keefe EB: Natural history and treatment of hepatitis $B$ virus and hepatitis $C$ virus coinfection. Ann Clin Microbiol Antimicrob 2005;4:13.

29 Weltman MD, Brotodihardjo A, Crewe EB, et al: Coinfection with hepatitis B and C or B, C and delta viruses results in severe chronic liver disease and responds poorly to interferonalpha treatment. J Viral Hepat 1995;2:39-45.

30 Kim SU, Kim JK, Park YN, Han KH: Discordance between liver biopsy and FibroScan ${ }^{\circledR}$ in assessing liver fibrosis in chronic hepatitis B: risk factors and influence of necroinflammation. PLoS One 2012;7:e32233.

31 Zhu X, Wang LC, Chen EQ, et al: Prospective evaluation of FibroScan for the diagnosis of hepatic fibrosis compared with liver biopsy/ AST platelet ratio index and FIB-4 in patients with chronic HBV infection. Dig Dis Sci 2011; 56:2742-2749.

32 Sanai FM, Keeffe EB: Liver biopsy for histological assessment: the case against. Saudi J Gastroenterol 2010;16:124-132.

-33 Celikbilek M, Dogan S, Gursoy S, et al: Noninvasive assessment of liver damage in chronic hepatitis B. World J Hepatol 2013;5:439445 . 